\title{
CULTURAL CODES AND BRAND EQUITY RELATIONS - EXPLORATORY STUDY AND RESEARCH IMPLICATIONS
}

\author{
Monika Hajdas \\ Wrocław University of Economics, Wrocław, Poland \\ e-mail: monika.hajdas@ue.wroc.pl \\ ORCID: 0000-0003-1006-2486 \\ (C) 2019 Monika Hajdas \\ This is an open access article distributed under the Creative Commons Attribution-NonCommercial-NoDerivs license \\ (http://creativecommons.org/licenses/by-nc-nd/3.0/)
}

DOI: $10.15611 / \mathrm{ms} .2019 .1 .03$

JEL Classification: M30, M31, M37

\begin{abstract}
The aim of the paper is to explore the possible relationships between cultural brand narration and brand equity. The concept of cultural branding has been developed in marketing literature, but there are no studies showing the outcomes of building brand narrations based on residual, dominant and emergent cultural codes and whether these outcomes include effects connected with brand equity. The paper is based on multiple case research. As a result, the author suggests cultural brand narration as an independent variable, and brand equity dimensions as dependent variables. The author then forms one theory proposition and three hypotheses on the relationships between those variables. Based on multiple case research the author suggests that conservative brand narration relates negatively to brand-related effects, whereas popular and progressive brand narrations relate positively to brand-related effects.
\end{abstract}

Keywords: brand equity, cultural branding, cultural codes, multiple case research.

\section{Introduction}

Brand research emerged from management discipline and initially it focused on measuring brand effects [Keller, Lehmann 2006]. The main research stream revolved around issues connected with brand identity - planned and performed by companies, and its outcome in the form of brand image in consumers' minds, which led to purchase behavior [Keller 1993]. This perspective included two main role players in brand building processes, companies and consumers. However, more researchers highlight that companies and consumers are not the only subjects in brand building processes and indicate the increasing recognition of how culture shapes consumer behavior and the meaning of brands [Holt 2004; Holt and Cameron 2010;, Schroeder 2009; Oswald 2012]. The cultural perspective complements economic views on consumption patterns and management views on branding. It also complements brand identity and brand image categories and opens up new interpretation possibilities connected with brand image distortions
[Schroeder 2009]. The new branding approach, defined by Holt [2004] as cultural branding, has been explored by several researchers [McCracken 2005; Schroeder, Salzer-Mörling 2006; Allen et al. 2008; Holt Cameron 2010; Rossatolos 2013], so we may witness the birth of a new branding paradigm in which the marketer represents one of many relevant meaning makers, next to consumers and broader cultural conventions [Allen et al. 2008]. Keller and Lehmann [2006] even suggested that "brand equity is increasingly built by activities outside the company's direct control".

However there has been very little research on cultural branding's relation to brand equity. The focus of this paper is on how brand value may be created by understanding the evolution of cultural models in society and building brand narrations on the observed changes. The paper is organized as follows. Section 2 describes the main concepts used in the research, that is brand equity and cultural branding. Section 3 describes the multiple case research method, Section 4 presents the results and theory proposition in the 
form of a hypothesis and research model. Finally, Section 5 presents the conclusions.

\section{Theoretical framework}

\subsection{Brand equity}

The concept of brand equity emerged in the 1990s as a pivotal element in the brand management research stream [Aaker 1991; Keller 1993]. Since then the discourse on brand equity has split into two main themes: financial-based brand equity [Smith 1991; Simon, Sullivan 1993] and customer-based brand equity [Aaker 1991; Keller 1993]. From the financial point of view, brand equity was first defined by Brodsky [1991] as the sale and profit impact enjoyed as a result of the previous year's marketing efforts versus a comparable new brand. Aaker [1991] defined customer-based brand equity as a set of brand assets and liabilities linked to a brand, its name and symbol that add to or subtract from the value provided by a product or service to a firm and/ or to that firm's customers. Keller [1993] defined customer-based brand equity as the differential effect of brand knowledge on consumer response to the marketing of the brand. Aaker's [1991] and Keller's [1993] brand equity models provided a framework for other researchers. Based on their framework, Yoo and Donthu [2001] developed and validated a multidimensional scale for measuring customer-based brand equity using four main dimensions: brand awareness, brand association, perceived quality and brand loyalty.

Keller [1993] noted that the definition of customer-based brand equity does not distinguish that there may be various sources of brand beliefs, which may be created by the marketer or by some other influencers such as reference groups or publicity. Schroeder [2009] highlighted the role of cultural conventions in brand building processes. He indicated that the brand equity concept is rooted in management and marketing disciplines, and lacks a socio-cultural perspective. He also suggested that the process of creating and delivering brand value, which results in building brand equity, is strongly influenced by cultural codes [Schroeder 2009].

\subsection{Cultural branding}

The term cultural branding was put together and formally introduced by Holt [2004]. However the socio-cultural perspective in marketing literature started to appear much earlier and was built upon several theories and concepts grounded in an interpretive research paradigm [Sherry 1991]. The main disciplines and concepts that became the cornerstone for the development of the cultural branding approach include semiology [Barthes 1964], the anthropology of consumption [McCracken 1986], the concept of symbolic consumption [Levy 1959; Douglas, Isherwood 1979; Belk 1988], practice theory [Reckwitz 2002], Consumer Culture Theory [Arnould, Thompson 2005; Sherry, Fisher 2009], and marketing semiotics [Oswald 2012].

Holt [2004] defined cultural branding as aligning the brand with the right cultural ideal in a credible and appealing way in marketing communication. This type of brand positioning based on socio-cultural issues is defined by Rossatolos [2013] as brand narrative. Holt and Thompson [2004] view cultural ideals as discourses which shape what people want, say and do. Companies therefore should search for appropriate ideas (cultural ideals) in broader cultural categories and turn those ideas into brand narratives. McCracken [2005] indicated key cultural meaning categories, such as gender meanings, lifestyle meanings, age and cohort meanings, occupation meanings, class and status meanings, decade meanings, time and place meanings, value meanings, and fad/fashion/trend meanings [Allen et al 2008]. According to Holt [2004], the branding potential lies in identifying common anxieties people experience when faced with cultural norms. These anxieties may regard categories such as: college graduation, gender roles and sexuality, people's ambitions at work, their dreams for their children, their fears of technology, mid-life crisis or retirement. These categories form a cultural landscape allowing companies to identify and select ideas that would fit the desired brand image. Holt suggests [2004] that when selecting cultural ideals for a brand narrative, companies should investigate whether a consumer identifies himself/herself with the ideal.

In cultural branding the brand is perceived from the semiotic point of view as a sign entity. In Peirce's [1998] semiotic theory, signs play two main roles: to stand for something (the object) and to have the ability to create an effect in the mind (interpretant) [PintoSanto 2013]. Signs form bigger units of semiotic analysis, which are codes. Cultural codes are defined as symbols and systems of meaning that are relevant to members of a particular culture [Hyat, Simons 1999]. Branding is the process of creating visual and verbal cues in order to build a certain image. So in fact brands are immersed in a meaning system. Or, as Taylor [2010] puts it: Brand is culture, culture is brand.

As the culture is not static, the cultural codes should be investigated in two ways: from the synchronic perspective (moment in time) and the diachronic 
perspective (evolution of codes over time) [Oswald 2012]. The framework allowing to investigate cultural codes over time is the RDE analysis, based on the concept of residual, dominant and emergent cultural codes, distinguished by Williams in 1981 [Mahtabi, Eslamieh 2015], where residual means former cultural ideas, objects, symbols or practices - rooted in the past, lacking impact on the modern world. Dominant codes are the current issues, mainstream, widely known and accepted. The emergent codes are new, fresh perspectives [Oswald 2012]. This concept enables us to understand how socio-cultural paradigms evolve over time [Mahtabi, Eslamieh 2015].

Mixing a variety of cultural categories with residual, dominant and emergent codes that can be identified within these categories seems to offer endless branding options for companies. Oswald [2012] gives the example of evolving the meaning of retirement and indicates residual codes (retirement as "the clinic"), dominant codes ("the cruise") and emergent codes ("the road trip"). Companies offering products or services addressed to retirees can look for brand ideas within these codes. But which of these approaches would actually pay off? Which cultural ideals, coming from the past, present or future would gain consumers' recognition and appreciation? Several researchers have investigated the concept of retro branding [Brown, Kozinets, Sherry 2003], where the past played a significant role in brand positioning. They defined retro branding as "the revival or relaunch of (...) a brand from a prior historical period, which is usually but not always updated to contemporary standards of performance, functioning or taste." The authors point out that in such cases some association with the past should be kept in order to achieve a distinctive feeling of nostalgia. It seems however that their research regards the past in terms of some physical qualities or attributes of the product, such as shape or design, not past cultural ideals per se. Alexander [1996] suggested that when a culture evolved in a certain direction, no company could stop it. Using residual codes in such a situation might impute that a brand is outdated. Oswald [2012] stresses that residual codes are those that have lost their luster and are unfashionable. But the results of using past ideas in brand narration remain underexplored. Verganti [2009] underlines the future perspective and suggests that companies who wish to launch innovation should opt for a visionary approach and search for new (emergent) cultural codes. In his opinion the main challenge for visionary brands is to understand the evolution of socio-cultural models, and propose new visions and meanings [Verganti 2009].
With the rise of the cultural branding paradigm, new research directions occur. Despite it being 15 years since the introduction of the term by Holt [2004], the cultural branding theory still seems to be underdeveloped - there are no studies indicating ways to build cultural narratives based on changing sociocultural models and the outcomes of those actions for brand equity. The main research question in this paper is: what are the possible relations between the two central concepts, brand equity and cultural branding? This research gap led us to pursue the inductive, exploratory case study approach described next. The applicability of William's framework of dominant, emergent, and residual codes to brand analysis is demonstrated through the discussion of six case studies. The aim is to explore the possible relations between brand narratives built on residual, dominant and emergent codes and brand equity.

\section{Research method}

\section{Research design}

To accomplish the research goal, multiple case research was conducted. Such a method enables "replication" logic [Yin 1984], which means that a series of cases is treated like a series of experiments, and each case study allows to confirm or reject the observations made in previous ones. Although a multiple case design is more challenging than a single case, it enables the induction of more reliable models [Bourgeois, Eisenhardt 1988].

\section{Case selection}

In selecting suitable cases theoretical sampling was applied, aiming to look for a sample which is representative in terms of the researched concepts [Strauss and Corbin 1998]. In exploratory research, the theoretical selection of cases is sufficient and even indicated [Eisenhardt, Graebner 2007]. This means that the cases are selected intentionally due to their particular usefulness in exposing relationships between the studied constructs and the findings allow generalization in analytical meaning (as theoretical propositions), but not in the statistical meaning (as a frequency of occurrence) [Yin 2003]. The author searched for brands that have used the cultural branding approach and selected six cases. As Table 1 indicates, the examined cases capture the variety of product categories and geographical coverage.

\section{Data sources and gathering}

Case research can be based on various data sources. In exploratory research, qualitative data dominate [Eisenhardt, Graebner 2007], and in the semiotic approach the main research method is content 
analysis [Oswald 2012]. In the first research phase the content analysis of brand strategic messages and their creative executions (commercial videos, print and outdoor advertisements, brand mission statements) was performed aiming at identifying broad cultural categories (such as gender or power) that brands were operating in, and the "semiotic cues" [Oswald 2012] they have used in their narratives such as images, words and stories that together formulate a specific cultural code.

Table 1. Cases selected for the research

\begin{tabular}{|c|l|l|l|}
\hline $\begin{array}{c}\text { Case } \\
\text { number }\end{array}$ & Brand & $\begin{array}{c}\text { Product } \\
\text { category }\end{array}$ & $\begin{array}{c}\text { Geographic and } \\
\text { temporal coverage } \\
\text { of analyzed strategy }\end{array}$ \\
\hline C1 & Dove & Cosmetics & Global, 2004 and 2015 \\
\hline C2 & Dockers & Clothes & USA, 2009 \\
\hline C3 & Rom & Food & Romania, 2010 \\
\hline C4 & Tołpa & Cosmetics & Poland, 2014 \\
\hline C5 & Barbie & Toys & USA, 2015 \\
\hline C6 & Lynx & Cosmetics & UK, 2016 \\
\hline
\end{tabular}

Source: own elaboration.

When possible, content analysis was enriched with industry expert opinions found in secondary sources. In the second research phase, data on the results of the cultural branding approach obtained by each of the brands was gathered. In one case it was possible to conduct a face-to-face in-depth interview with a former marketing director responsible for the brand strategy. The research tool was a semi-structured interview scenario. For the remaining cases secondary sources were used, including industry-specific media and experts opinions, market reports and company press releases.

\section{Data analysis and presentation}

Following Eisenhardt [1989], within-case data was analyzed to examine the relationship between brand narration and type of cultural code it was based on and the results it obtained. Cross-case patterns and similarities were also analyzed to understand which cultural categories and codes were present across cases and if they were able to provide similar results. This was conducted through the categorization of brands by the broad cultural categories they exploited, according to McCracken's [2005] and Holt's [2004] propositions and by cultural codes according to William's [1981] framework. Space constraints make it difficult to provide "thick description" for each case [Geertz 1973, [in:] Ponterotto 2006], but in the next section the main cultural narratives that were used by each brand are briefly presented.

\section{Results}

\subsection{Six brands and their cultural ideals - narrative descriptions}

\section{4}

Dove "Campaign for Real Beauty", global, since

In 2004 Dove, the global cosmetics brand from the Unilever portfolio, started a cultural conversation about the definition of beauty which has led the brand to a position of a global leader in personal care and its advertising strategy became an industry benchmark for marketing to women. Dove questioned the convention of marketing to women in the beauty industry, which was based on appearance anxieties and has relied on idealized portrayals of women [Simmons 2006], but it also questioned a wider aspect of contemporary culture, to be precise the definition of beauty created by the media and popular culture. The initial Campaign for Real Beauty was launched in 2004 and was based on billboards showing real women and reflecting the variety of female beauty, in terms of age, body shape and size, hair color, etc. The campaign's results were as follows [Holmes 2006]: more than 1,000 placements in print, online, television and radio outlets, generating 630 million media impressions during the summer of 2005; brand sales at the peak of the PR campaign, from June to August, were up 24 percent over the same period in 2004. More than 1.5 million women around the world have visited campaignforrealbeauty.com and shared words of appreciation. In the U.K. market, Dove's brand metrics rose and outperformed their competitor, Lux, on brand awareness (69.2\% to $30.8 \%$ ), and on brand acceptance $(7.56 \%$ to $4.73 \%)$, with acceptance rising significantly [Holmes 2006]. Another campaign - Real Beauty Sketches - based on the same cultural insight was released in 2013. The video clip had over 35 million viewers within two weeks of being posted on YouTube [Aaker 2017]. Eventually it received 163 million global views, became "the most watched video ad of all time" [Murphy 2013], was chosen \#1 on the Cannes YouTube Ads Leaderboard and won the Titanium Grand Prix at the 2013 Cannes Lions International Festival of Creativity.

The brand narrative was based on the body perception category, not mentioned by McCracken or Holt, and the emergent code of body-positivity.

Dockers "Time to wear the pants", USA 2009

In December 2009 the Dockers brand of khaki pants launched an advertising campaign with the tagline "Wear The Pants", featuring in radio, print, poster, online advertising and social media [Macleod 2009]. The campaign began with a manifesto - the 
text describing the culture's lost masculinity and was marketed as a call to masculinity for men [Palczewski et al. 2018]. The text of the manifesto explained the major shifts in a society: "Once upon a time, men wore the pants. (...) Men took charge because that's what they did. (...) But somewhere along the way the world decided it no longer needed men (...)". In the next sentences the text urged man to "get their hands dirty" and "wear the pants" in their families. Soon after the campaign was released, several harsh comments appeared in the media from industry experts and journalists, describing the campaign as sexist [Cullers 2009], homophobic and misogynic [Falcone 2009], patronizing and backwards [Smith 2009], and asserting its manifesto of old-fashioned assumptions [Burk]. There were also some later comments stating that the campaign had tried to reanimate gendered labour [Negra, Tasker 2014]. One of the journalists concluded her article on the campaign: "Wear the pants? We all should. Just not Dockers" [Falcone 2009].

The brand narrative was based on the gender roles category and residual code of masculinity.

Rom "American Rom", Romania 2010

"Rom" is the traditional chocolate bar that all Romanians grew up with, enjoying 95\% brand awareness. Since 1964 the brand name has represented the nation, the packaging shows the national flag and the brand contains all the associations involved, including its communist past. The problem for the brand was an ageing, nostalgic consumer base and the young generation who preferred cool American brands and for whom Rom was becoming meaningless [Fera 2011; Macleod 2011]. In fact only $12 \%$ of young people described themselves as patriots. The company decided to challenge the national ego and developed a campaign staged to look like an American takeover, i.e. replacing the Romanian flag on the packaging with the American one. Young Romanians took it as an insult (the controversy was the company's purpose) and wanted 'the old' Rom back. After several days, a reveal phase reassured consumers that Rom remained Romanian and its usual wrapping was restored [WARC 2012]. The results of these actions connected with the increase in brand popularity were as follows [Fisher 2011]: 67\% of reach among Romanians; 75 thousand of unique visitors to the web page in the first six days of the campaign; the number of Facebook fans increased by $300 \%$ in the first six days of the campaign. There were also results in brand image [ROMAmerican 2011]: all brand image indicators exploded, especially "Rom is the brand for me", which more than doubled, with a $124 \%$ increase.
In terms of brand preference and sales, Rom became Romania's favorite chocolate bar, with a 79\% increase of the indicator. It also outperformed the market, with $20 \%$ growth (compared to a $8.2 \%$ category growth) in the most relevant channels, hypermarkets. The campaign won the 2012 Warc Prize for innovation in the communication category [WARC 2012] and two Grands Prix prizes in the promo/activation and direct categories during the Cannes Lions International Festival of Creativity [AdAge 2012].

The brand narrative was based on the cohort cultural category and dominant code of Americanization.

Totpa "Buy Less", Poland, 2013-2015

In 2013 a small Polish cosmetics brand launched a communication strategy called Buy Less. The brand decided to challenge modern buying patterns, especially impulsive shopping, which can be observed in many aspects of life, not just cosmetics [Pełka-Szajowska 2014]. Through various marketing activities, the brand urged consumers to choose smart, buy less and opt for better quality. During the interview our informant stated that although the concept seemed risky, the timing was right. There was a new consumer trend on the horizon, i.e. minimalism, the brand was small and has always had a modest approach to marketing, in a category where the key players had huge marketing budgets and took over the mass media. The idea seemed to be distinctive and fit the brand values. The company decided to carry out rebranding of 160 products. Everything was verified according to the new idea, from product recipes, which were simplified, through packaging design, web site and above all, the brand language, which was designed to be more friendly, real and human. In 2013, soon after the strategy's launch, the brand was awarded several industry prizes: best advertising campaign in Poland ( Kreatura 2013 contest), best rebranding, and best website (Webstar 2013), Dobry Wzór 2013 prize. Since the launch of the strategy the brand has been awarded over 40 prizes by both the industry and consumers for their products and communication concept. The brand has significantly improved its market position, becoming in 2017 one of the best known Polish cosmetics brands. In 2018 Tołpa won the Superbrands Polska Marka 2018 (Polish Brand 2018) title [Superbrands Polska 2018]. Our informant confirmed that brand awareness has risen significantly since the launch of the strategy, despite incomparably lower promotion expenditure comparing to its main competitors.

The brand narrative was based on the lifestyle cultural category (anti-consumerist) and the emergent minimalism code. 
Barbie "Imagine the Possibilities", USA, 2015

Barbie faced a brand image problem: it was perceived as an outdated collection of stereotypes, setting an unrealistic standard of physical beauty [Townsend 2018]. The decision was made that, instead of showing typical product spots with the doll and her latest accessory, the "Imagine the Possibilities" campaign would focus on girls' future and would feature girls playing out what they want to be when they grow up (a vet, a museum guide, a college professor, etc.) [Writer 2016]. The campaign managed to reverse 12 consecutive quarters of declining sales in just three months. One video delivered a total of 709 million PR impressions and was soon watched by over 50 million people, switching the conversation from what Barbie looks like to the possibilities she awakens in little girls [Effie, 2017]. The campaign helped lift the brand's affinity scores, according to Mattel [Townsend 2018]. The brand reported an 81\% positive impact on the brand among mothers of girls aged 2-10. The video was named YouTube Ad of the Year in 2015 [Contagious 2016].

The brand narrative was based on parents dreams of their children's future and gender roles and used the emergent code of fempowerment movement.

\section{Lynx "Men in progress", UK, 2016}

The LYNX deodorant brand (AXE in France and some other markets), for a decade has been targeting young men with a brand image based on the promise that the products would help them attract women. This image was connected with the so-called 'laddish culture' of the 1990s and was not appealing to young men anymore. Instead of yet another 'getting the girl' ad, the brand came up with the "Men In Progress" series of videos. LYNX started a cultural conversation on contemporary manhood, letting men challenge the traditional views of being a man. The men in the videos discussed a range of personal topics, like the last time they cried, their feelings about their physique, and even their relationship with their father. All male perspectives were included in the nine videos, from love of football to loathing it [TMW Unlimited 2016]. The results were outstanding, before all the films were released the series had achieved a combined organic reach of 650 thousand, along with 1.4 million paid views. The films have gained combined PR reach of over 109 million. Half of the men who saw the video said that the content alone made them reappraise the brand's relevancy [DMA 2017]. Moreover, an analysis of the financial value of the biggest brands on the British market clearly showed that this approach has worked for Lynx. Brand Finance highlighted that Lynx is Britain's fastest growing brand, up 91 per cent to £2.1billion [Brand Finance 2017].
The brand narrative was based on gender roles and used the emergent code of multi-masculinity.

Table 2 presents a summary of multiple case research.

Table 2. Summary of six brands' cultural narratives

\begin{tabular}{|c|c|c|c|c|}
\hline $\begin{array}{c}\text { Case } \\
\text { number }\end{array}$ & $\begin{array}{c}\text { Brand } \\
\text { (strategy) }\end{array}$ & $\begin{array}{l}\text { Cultural } \\
\text { category }\end{array}$ & Brand narrative & $\begin{array}{c}\text { Impact on } \\
\text { brand equity }\end{array}$ \\
\hline $\mathrm{C} 1$ & $\begin{array}{l}\text { Dove } \\
\text { (Real } \\
\text { Beauty) }\end{array}$ & $\begin{array}{l}\text { Body / } \\
\text { gender }\end{array}$ & $\begin{array}{l}\text { Emergent: } \\
\text { body positivity }\end{array}$ & $\begin{array}{l}\text { Increase in } \\
\text { brand } \\
\text { awareness } \\
\text { Increase in } \\
\text { brand } \\
\text { acceptance }\end{array}$ \\
\hline $\mathrm{C} 2$ & $\begin{array}{l}\text { Dockers } \\
\text { (Time to } \\
\text { Wear the } \\
\text { Pants) }\end{array}$ & Gender roles & $\begin{array}{l}\text { Residual: } \\
\text { macho man }\end{array}$ & $\begin{array}{l}\text { Public } \\
\text { critique } \\
\text { - brand } \\
\text { image }\end{array}$ \\
\hline $\mathrm{C} 3$ & $\begin{array}{l}\text { Rom } \\
\text { (American } \\
\text { Rom) }\end{array}$ & Cohort & $\begin{array}{l}\text { Dominant: } \\
\text { americani- } \\
\text { zation }\end{array}$ & $\begin{array}{l}\text { Improvement } \\
\text { in all brand } \\
\text { image } \\
\text { indicators }\end{array}$ \\
\hline $\mathrm{C} 4$ & $\begin{array}{l}\text { Tołpa } \\
\text { (Buy Less) }\end{array}$ & $\begin{array}{l}\text { Lifestyle } \\
\text { (anti- } \\
\text { consumerist) }\end{array}$ & $\begin{array}{l}\text { Emergent: } \\
\text { minimalism }\end{array}$ & $\begin{array}{l}\text { Increase in } \\
\text { brand } \\
\text { awareness } \\
\text { and } \\
\text { distinctive } \\
\text { brand image }\end{array}$ \\
\hline $\mathrm{C} 5$ & $\begin{array}{l}\text { Barbie } \\
\text { (Imagine the } \\
\text { Possibilities) }\end{array}$ & $\begin{array}{l}\text { Age/gender/ } \\
\text { parents } \\
\text { dreams for } \\
\text { their } \\
\text { children }\end{array}$ & $\begin{array}{l}\text { Emergent: } \\
\text { fempowerment }\end{array}$ & $\begin{array}{l}\text { Increase in } \\
\text { brand's } \\
\text { affinity }\end{array}$ \\
\hline C6 & $\begin{array}{l}\text { Lynx } \\
\text { (Men in } \\
\text { Progress) }\end{array}$ & Gender & $\begin{array}{l}\text { Emergent: } \\
\text { emotional } \\
\text { masculinity }\end{array}$ & $\begin{array}{l}\text { Increase in } \\
\text { brand } \\
\text { relvancy } \\
\text { Increase in } \\
\text { financial } \\
\text { brand value }\end{array}$ \\
\hline
\end{tabular}

Source: own elaboration.

Based on the obtained results, the next section provides an analytical generalization in the form of a theory proposition, hypothesis and research model.

\subsection{Hypothesis and research model}

Findings show that the decisions to use body positivity emergent code (Dove, C1), macho man residual code (Dockers, C2), Americanization dominant code (Rom, C3), minimalism emergent code (Tołpa, C4), fempowerment emergent code (Barbie, C5) and multi-masculinity emergent code (Lynx, C6) in brand narratives, were all critical decisions which had an impact on brand results. The patterns observed across these case studies allow to draw inferences regarding the impact of the cultural code present in brand narration on brand equity. Here the general proposition is presented and then developed into specific hypotheses. 
PROPOSITION: Cultural brand narration relates to brand equity.

In the conducted study, the brand that used a conservative narration set in the gender context (C2) did not report the brand success in public, as other brands from the study did. It also did not report any industry awards, which usually becomes a publicity topic for companies. Instead, some critical public opinions were found among industry observers and experts regarding the content of the strategy, which might have affected brand image. The company did not continue the strategy in the long term. This would confirm Alexander's [1996] suggestion that a brand cannot stop the evolution of culture. This would also question the circumstances that make the past attractive in retro branding approach [Brown, Kozinets, Sherry 2003]. Thus:

H1a: Conservative brand narration relates negatively to brand-related effects.

In the conducted study, one brand set their narrative in a cohort context and used the dominant cultural code (C1). The results they obtained allow to suggest that brand narration based on the dominant cultural code adds to brand equity. Thus:

H1b: Popular brand narration relates positively to brand-related effects.

In the conducted study three brands used the emergent cultural code, two of them set their narratives in the gender context (C5 and C6) and one set their narrative in the lifestyle context (C4). The findings demonstrate that brands using progressive narrations experienced increases in terms of brand affinity and brand popularity. All three brands earned marketing industry recognition and gained awards for the results of their campaigns. For one of these brands (C6), an independent consulting company reported a significant increase in financial brand value. The results obtained by brands allow to suggest that brand narration based on an emergent cultural code adds to brand equity. This confirms Verganti's [2009] perspective on companies' actions aimed at changing socio-cultural paradigms. Thus:

H1c: Progressive brand narration relates positively to brand-related effects.

This proposition and hypotheses were prompted by the obtained data. They may be treated as, what Yin [2003] refers to, analytical generalizations, meaning they summarize the observed uniformities of relationships between variables: where the independent variables are conservative, popular and progressive brand narrations, and dependent variables are brand-related effects, dimensions of brand equity. These propositions and hypotheses may be also treated as a research proposal, the theoretical model summarized in Figure 1.

\section{Conclusions}

The conducted multiple case research contributes to the existing knowledge by highlighting the possibilities of new relationships not researched before: between

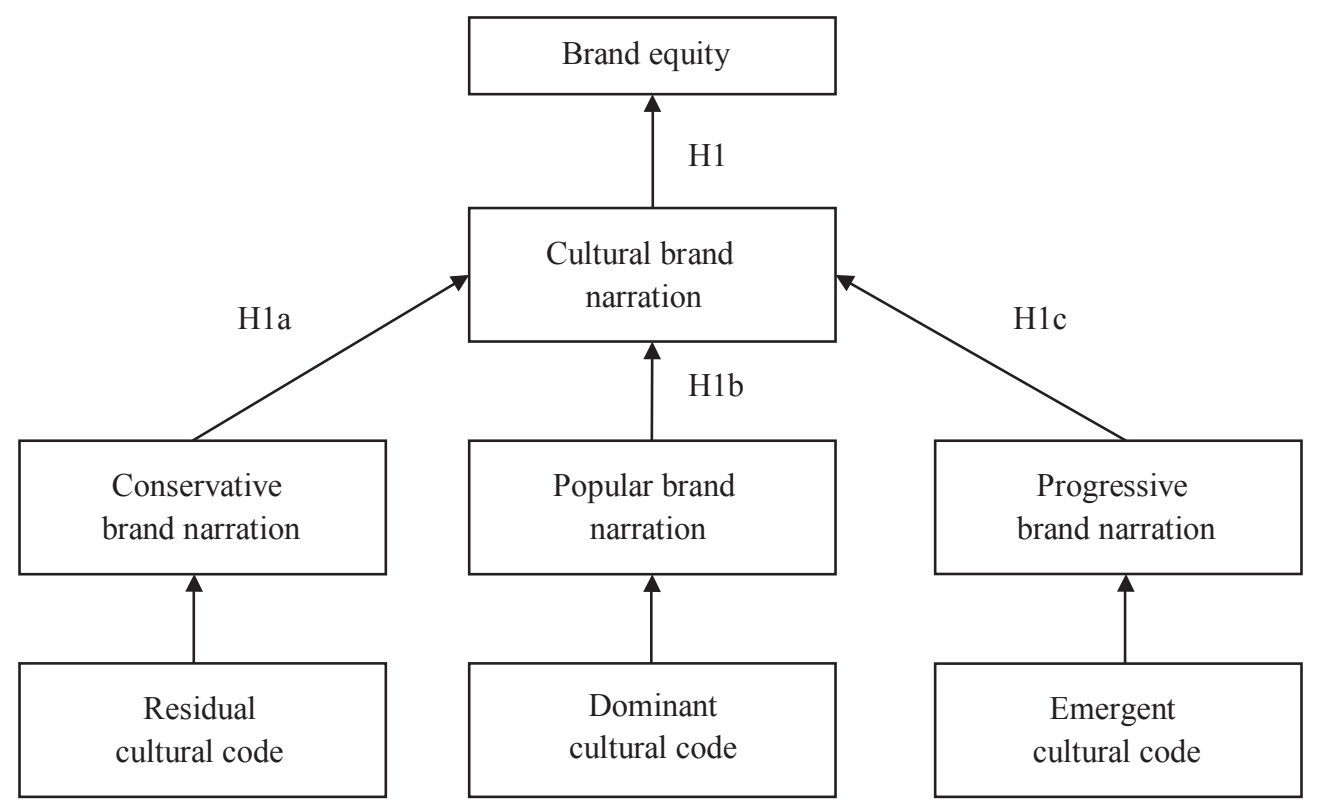

Fig. 1. A model of relations between cultural codes in brand narration and brand equity

Source: own elaboration. 
the type of cultural code used for brand narration and brand equity dimensions. The following managerial implications result from the research: managers should be careful when using brand narrations based on residual code as such a decision may have a negative impact on brand equity. Such narrations require testing and verifying whether they are not associated with outdated issues. Managers should consider using brand narrations based on dominant and emergent cultural codes as such decisions may have a positive impact on brand equity. The following social implications result from the research: brand narrations based on dominant and emergent codes can bring benefits not only to companies, but they may also help eliminate negative stereotypes and evoke the expected cultural transformation. The main limitation of the study is its exploratory nature and the secondary sources used in most cases. Therefore the hypotheses suggested require testing in experimental (quantitative) studies.

\section{Bibliography}

Aaker D.A., 1991, Managing Brand Equity, The Free Press, New York.

Aaker D., 2017, What We Can Learn from Dove's Brand Portfolio Growth, https://www.prophet.com/2017/06/doves-brand-portfolio-growth/ (28.12.2018).

AdAge, 2012, American Express Small-Business Effort Wins First Two Grand Prix, https://adage.com/article/special-report-cannes-2012/cannes-lions-amex-small-business-effortwins-grand-prix/235438/ (10.01.2019).

Alexander M., 1996, Codes and contexts, MRS Conference 1996, www.semioticsolutions.com/pdf/Codes\%20\&\%20 contexts. $\operatorname{pdf}(27.11 .2011)$.

Allen Ch.T., Fournier S., Miller F., 2008, Brands and Their Meaning Makers, [in:] Handbook of Consumer Psychology, C.P. Haugtvedt, P. Herr, F.R. Kardes (eds), Taylor \& Francis, pp. 781-822.

Arnould E., Thompson C. \& [Dawn Iacobucci served as editor for this article], 2005, Consumer culture theory (CCT): twenty years of research, Journal of Consumer Research, 31(4), pp. 868-882. doi:10.1086/426626.

Azar Salim L., 2013, Exploring brand masculine patterns: moving beyond monolithic masculinity.

Barthes R., 1964, Elements of Semiology, Hill and Wang, New York.

Belk R.W., 1988, Possessions and extended self, Journal of Consumer Research, 15/2, pp. 139-68.

Bourgeois L.J., III, Eisenhardt K.M., 1988, Strategic decision processes in high velocity environments: four cases in the microcomputer industry, Management Science, vol. 34, no. 7 (July 1988), pp. 816-835.

Brand Finance, 2017, United Kingdom 150, The annual report on the most valuable British brands, http://brandfinance. com/images/upload/brand_finance_uk_150_2017_locked. pdf (25.12.2018).

Brodsky J., 1991, Issues in Measuring and Monitoring, paper presented at the ARF Third Annual Advertising and Promotion Workshop.
Brown S., Kozinets R., Sherry J., 2003, Teaching old brands new tricks: retro branding and the revival of brand meaning, Journal of Marketing, vol. 67, pp. 19-33.

Burk M.S., Dockers tries to man up. Shoots self in groin, http:// www.makebrilliantideas.com/ad-brilliance/dockers-tries-to-man-up-shoots-self-in-groin/ (10.01.2019).

Contagious, 2016, How brands can change attitudes, https:// www.wfanet.org/app/uploads/2017/06/How-Brands-Can-Change-Attitudes_Contagious-IO.pdf (28.12.2018).

Cullers R., 2009, Dockers' man-ifesto gets a kick in the pants, Adweek, https://www.adweek.com/creativity/dockers-man-ifesto-gets-kick-pants-13254/ (29.12.2018).

DMA, 2017, 2017 Silver Best brand building campaign, https:// dma.org.uk/awards/winner/2017-silver-best-brand-building-campaign (10.01.2019).

Douglas M., Isherwood B., 1979, The World of Goods: Toward an Anthropology of Consumption, Routledge Press, New York.

Effie, 2017, Barbie Imagine the Possibilities, https://www.effie.org/ case_database/case/NA_2017_E-2196-660 (28.12.2018).

Eisenhardt K., 1989, Building theories from case study research, The Academy of Management Review 14(4), pp. 532-550.

Eisenhardt K., Graebner M., 2007, Theory building from cases: opportunities and challenges, Academy of Management Journal, vol. 50, no. 1 , pp. 25-32.

Falcone L.B., 2009, Sexist Dockers ad Leaves us Hemming and Hawing, Boston Herald, https://www.bostonherald. com/2009/12/10/sexist-dockers-ad-leaves-us-hemming-and-hawing/ (29.12.2018).

Fera R.A., 2011, How A Candy Bar Wrapper Ignited Romanian Pride And Won McCann Two Grand Prix, Fast Company, https://www.fastcompany.com/1761932/how-candy-barwrapper-ignited-romanian-pride-and-won-mccann-twogrand-prix (25.12.2018).

Fisher A., 2011, When bad advertising goes good...ROM chocolate bar, https://www.orchard.co.uk/blog/when-bad-advertising-goes-goodrom-chocolate-bar-1349.aspx (10.01.2019).

Geertz C., 1973, The Interpretation of Cultures: Selected Essays, Basic Books, New York.

Holmes P., 2006, Real Beauty in the Age of the Extreme Makeover, https://www.holmesreport.com/long-reads/article/real-beauty-in-the-age-of-the-extreme-makeover (28.12.2018).

Holt D., 2004, How Brands Become Icons, Harvard University Press.

Holt D., Cameron D., 2010, Cultural Strategy, Oxford University Press, New York.

Holt D., Thompson C.J., 2004, Man-of-action heroes: the pursuit of heroic masculinity in everyday consumption, Journal of Consumer Research, 31 (September), pp. 425-40.

Hyat J., Simons H., 1999, Cultural codes - who holds the key? The concept and conduct of evaluation in Central and Eastern Europe, Evaluation, vol. 5(1), pp. 23-41.

Keller K.L., 1993, Conceptualizing, measuring, and managing customer-based brand equity, Journal of Marketing, 57, pp. 1-22.

Keller K.L., Lehmann D.R., 2006, Brands and branding: research findings and future priorities, Marketing Science, vol. 25 , no. 6 .

Levy S.J., 1959, Symbols for sale, Harvard Business Review, 37 (July-August), pp. 117-24.

Macleod D., 2009, Dockers Wear The Pants, Inspiration Room, http://theinspirationroom.com/daily/2009/dockers-wear-the-pants/ (10.01.2019).

Macleod D., 2011, American Rom Takeover, Inspiration Room, $\mathrm{http} / / /$ theinspirationroom.com/daily/2011/american-rom-takeover/ (25.12.2018). 
Mahtabi R.O., Eslamieh R., 2015, Dominant, residual, and emergent: opposing forces hovering over John Dos Passos' U.S.A, International Journal of Applied Linguistics \& English Literature, vol. 4, no. 6; November 2015.

McCracken G., 1986, Culture and consumption: a theoretical account of the structure and movement of the cultural meaning of consumer goods, Journal of Consumer Research, 13 (June), pp. 71-84.

McCracken G., 2005, Culture and Consumption II: Markets, Meaning, and Brand Management, Indiana University Press, Bloomington.

Murphy S., 2013, Viral Dove Campaign Becomes Most Watched Ad Ever, Mashable, https://mashable.com/2013/05/20/ dove-ad-most-watche/? europe =true \#amX9as6K1EqO (7.01.2019).

Negra D., Tasker Y., 2014, Gendering the Recession: Media and Culture in an Age of Austerity, Duke University Press.

Oswald L.R., 2012, Marketing Semiotics. Signs, Strategies, and Brand Value, Oxford University Press.

Palczewski C.H., Pruin DeFrancisco V., McGeough D., 2018, Gender in Communication: A Critical Introduction (3 ed.), SAGE Publications.

Peirce C.S., 1998, The Essential Peirce. Selected Philosophical Writings, volume 2 (1893-1913), ed. The Peirce Edition Project, Indiana University Press, Bloomington.

Pełka-Szajowska A., 2014, Torf Corporation - Fabryka Leków/ tolpa. O pieleggnacji kupowania mniej, Marketing w Praktyce, no. 2.

Pinto-Santo F., 2013, Brands as semiotic molecular entities, Social Semiotics, vol. 23, no. 4, 507-516.

Ponterotto J., 2006, Brief note on the origins, evolution, and meaning of the qualitative research concept thick description, the qualitative report, vol. 11, no. 3 .

Reckwitz A., 2002, Toward a theory of social practices: a development in culturalist theorizing, European Journal of Social Theory.

Robertson T.S., Kassarjian H.H. (ed.), Handbook of consumer research, Englewood Cliffs, Prentice Hall, NJ, pp. 548-591.

ROMAmerican (2011), American ROM - case study, https:// www.youtube.com/watch?v=41DflcblJz8 (12.01.2019).

Rossatolos G., 2013, Brand equity planning with structuralist rhetorical semiotics: a conceptual framework, The Qualitative Report, vol. 18, Article 90, pp. 1-20.

Schroeder J.E., 2009, Cultural codes of branding, Marketing Theory, 9.

Schroeder J.E., Salzer-Morling M. (eds), 2006, Brand Culture, Routledge, London.
Sherry J., 1991, Postmodern Alternatives: The Interpretive Turn in Consumer Research, [in]:

Sherry J.F., Fischer E., 2009, Explorations in Consumer Culture Theory, Routledge.

Simon C., Sullivan M.W., 1993, The measurement and determinants of brand equity: A financial approach, Marketing Science, 12(1), pp. 28-52.

Smith J.W., 1991, Thinking about Brand Equity and the Analysis of Customer Transactions, [in:] Maltz E. (ed.), Managing Brand Equity: a Conference Summary, Marketing Science Institute, Cambridge, MA, pp. 17-18.

Smith H., 2009, The Dockers "Man-Ifesto": Pants, Pants, Devolution, https://jezebel.com/5420105/the-dockers-man-ifesto-pants-pants-devolution (10.01.2019).

Strauss A., Corbin J., 1998, Basics of Qualitative Research: Techniques and Procedures for Developing Grounded Theory, Sage, London.

Superbrands Polska, 2018, Baza case study Superbrands, http:// superbrands.pl/wp-content/uploads/2018/05/26-2018.pdf (29.12.2018).

Taylor B., 2010, Brand is culture, culture is brand, Harvard Business Review, 27 September, https://hbr.org/2010/09/brand-is-culture-culture-is-br (6.01.2019).

TMW Unlimited, 2016, LYNX. Men in progress, https://www. tmwunlimited.com/work/unilever-lynx-men-in-progress/ (10.01.2019).

Townsend M., 2018, Barbie is on a roll: The good news from Mattel's dismal quarter, The Spokesman-Review, http://www. spokesman.com/stories/2018/jul/29/barbie-is-on-a-roll-thegood-news-from-mattels-dis/ (28.12.2018).

Verganti R., 2009, Design Driven Innovation: Changing the Rules of Competition by Radically Innovating What Things Mean, Harvard Business Press.

WARC, 2012, Rom wins Warc Prize for Innovation, https://www. warc.com/newsandopinion/news/rom_wins_warc_prize for_innovation/29973 (10.01.2019).

Writer S., 2016, 2015: Barbie's 'Imagine the Possibilities'video goes viral, The Drum, https://www.thedrum.com/ news/2016/06/30/marketing-moment-91-barbie-s-imaginepossibilities-video-goes-viral (28.12.2018).

Yin R., 2003, Case Study Research: Design and Methods, SAGE.

Yoo B., Donthu N., 2001, Developing and validating a multidimensional consumer-based brand equity scale, Journal of Business Research, 52, pp. 1-14.

\section{KODY KULTUROWE A KAPITAŁ MARKI - BADANIE EKSPLORACYJNE I MODEL TEORETYCZNY}

Streszczenie: Celem artykułu jest eksploracja możliwych zależności pomiędzy narracją kulturową marki a kapitałem marki. Koncepcja narracji kulturowej marki jest rozwijana w literaturze marketingowej, brakuje jednak badań wskazujących na rezultaty działań polegających na wykorzystaniu rezydualnych, dominujących lub emergentnych kodów kulturowych w narracji marki - w postaci kapitału marki. Artykuł oparty jest na studiach przypadków. Rezultatem badań jest propozycja modelu badawczego, w którym narracja kulturowa marki jest zmienną niezależną, a kapitał marki zmienną zależną. Autorka proponuje następujące hipotezy wymagające weryfikacji w dalszych badaniach: konserwatywna narracja marki negatywnie wpływa na wybrane wymiary kapitału marki, popularna i progresywna narracja marki pozytywnie wpływa na wybrane wymiary kapitału marki.

Słowa kluczowe: kapitał marki, kulturowa strategia marki, kody kulturowe, stadium przypadku. 